\title{
Adherence ability of Staphylococcus epidermidis on prosthetic biomaterials: an in vitro study
}

\author{
This article was published in the following Dove Press journal: \\ International Journal of Nanomedicine \\ II October 2013 \\ Number of times this article has been viewed
}

\section{Takayuki Shida' \\ Hironobu Koseki' \\ Itaru Yoda' \\ Hidehiko Horiuchi' \\ Hideyuki Sakoda ${ }^{2}$ \\ Makoto Osaki' \\ 'Department of Orthopedic Surgery, Graduate School of Medicine, \\ Nagasaki University, Nagasaki, Japan; 2Division of Medical Devices, National Institute of Health Sciences, Tokyo, Japan}

Correspondence: Hironobu Koseki Department of Orthopedic Surgery, Graduate School of Medicine, Nagasaki University, I-7-I, Sakamoto, Nagasaki 852-850I, Japan

$\mathrm{Tel}+8195819732$ I

Fax +8I 958497325

Email koseki@nagasaki-u.ac.jp
Abstract: Bacterial adhesion to the surface of biomaterials is an essential step in the pathogenesis of implant-related infections. In this in vitro research, we evaluated the ability of Staphylococcus epidermidis to adhere to the surface of solid biomaterials, including oxidized zirconium-niobium alloy (Oxinium), cobalt-chromium-molybdenum alloy, titanium alloy, commercially pure titanium, and stainless steel, and performed a biomaterial-to-biomaterial comparison. The test specimens were physically analyzed to quantitatively determine the viable adherent density of the $S$. epidermidis strain RP62A (American Type Culture Collection [ATCC] 35984). Field emission scanning electron microscope and laser microscope examination revealed a featureless, smooth surface in all specimens (average roughness $<10 \mathrm{~nm}$ ). The amounts of $S$. epidermidis that adhered to the biomaterial were significantly lower for Oxinium and the cobaltchromium-molybdenum alloy than for commercially pure titanium. These results suggest that Oxinium and cobalt-chromium-molybdenum alloy are less susceptible to bacterial adherence and are less inclined to infection than other materials of a similar degree of smoothness.

Keyword: bacterial adhesion, implant, infection, surface character

\section{Introduction}

A wide variety of solid, artificial biomaterials are implanted in the human body for a range of different purposes and have made a significant contribution to medical progress. In the field of orthopedic surgery, biomaterials with particular mechanical characteristics are now being used more frequently and for a wide range of purposes, including prostheses and trauma plates/nails. However, one disadvantage with these biomaterials is that they provide a suitable site for bacterial colonization in implantrelated infection. ${ }^{1-3}$ When bacteria adhere to and proliferate on the biomaterial surface, they secrete mucopolysaccharides and form a biofilm. The biofilm that envelopes the bacteria protects them from the immune system and antibacterial agents, so implantrelated infections are extremely difficult to treat. Although various methods of prevention have been devised, implant-related infections still occur today in $0.2 \%-17.3 \%$ of cases of prosthetic orthopedic surgery. ${ }^{4-6}$ In addition to long-term antibiotic administration, many cases require surgery to remove and debride the implant and/or to implant a cement mold containing antibiotics to ameliorate the infection. Research into the problem of bacterial adhesion to biomaterials is therefore critically important from a clinical perspective.

Most implant-related infections are caused by the Staphylococcus species. ${ }^{7-10}$ Staphylococcus epidermidis, one of the most commonly isolated bacterial pathogens, is particularly capable of adhering to and aggregating on biomaterial surfaces, and it can 
form biofilms on many different biomaterials. ${ }^{10,11}$ The process of bacterial adherence is generally thought to be governed by van der Waals interactions, such that the bacteria reach the surface of the artificial material by overcoming energy barriers, through electrostatic repulsion, and then form colonies by way of reversible/irreversible adhesion. ${ }^{12,13}$ Research has shown that polysaccharide intercellular adhesin (PIA) plays an important role in bacterial adhesion as well as in biofilm formation. ${ }^{14-17}$ However, the exact mechanism of adhesion has yet to be determined because of the complex combination of numerous other factors related to the bacteria, the in vivo environment, and the artificial material involved.

The solid biomaterials used for clinical purposes are strictly regulated through standards, such as the International Organization for Standardization (ISO) and the American Society for Testing and Materials (ASTM). Biomaterials can be made of just a few kinds of standardized materials, depending on their application, including titanium, stainless steel, cobalt-chromium-molybdenum alloy (Co-Cr-Mo) and ultra-high-molecular-weight polyethylene. Oxinium is an oxidized zirconium-niobium alloy, commercialized as a new biomaterial in Japan in 2008. It is created by permeating the zirconium-niobium alloy with oxygen at a high temperature so that only a $5 \mu \mathrm{m}$ surface layer is changed to zirconium ceramic. As a result, Oxinium has the characteristic of low abrasion on sliding surfaces, like a ceramic, and is strong like a metal. It also contains almost no toxic metals. ${ }^{18}$

Steinberg et al reported differences in bacterial adhesion to two different material surfaces, titanium and titanium alloy. ${ }^{19}$ Recently, there have been a number of reports on the impact on bacterial adhesion of surface roughness, wettability, and other physical properties of the actual solid materials themselves. ${ }^{20-28}$ However, most of this research has been on dental implants, on the basis of conditions found in the mouth. ${ }^{25-28}$ There is little research into the adhesion of $S$. epidermidis to other medical materials used in clinical practice, and their results were mostly inconsistent. Olson et al investigated the adhesion of PIA-producing S. epidermidis on biomaterial surfaces and reported differences between the different types of material but did not discuss the causes or mechanisms involved. ${ }^{17} \mathrm{Ha}$ et al reported a more extensive adherence ability of biofilmforming S. epidermidis on a titanium alloy (Ti-6Al-4V) than on stainless steel and suggested this was the effect of the inherent characteristics and roughness of titanium but detailed values of roughness or wettability were not discussed. ${ }^{29}$

In this in vitro study, we compared and investigated the ability of $S$. epidermidis to adhere to surfaces made of solid materials that are actually used in clinical practice-Oxinium,
Co-Cr-Mo, titanium alloy, commercially pure titanium, and stainless steel - and that have a similar degree of smoothness, in order to eliminate any discrepancies due to the effect of surface roughness. We have found no previous research that focuses on the adherence capabilities of different biomaterials, including Oxinium.

\section{Materials and methods Specimen preparation}

We prepared circular specimens $(12 \mathrm{~mm}$ in diameter, $6 \mathrm{~mm}$ thick) from Oxinium (ASTM F2384), Co-Cr-Mo (ASTM F75, high carbon), Ti-6Al-4V (ASTM F136), commercially pure titanium (CP-Ti) (ASTM F67), and stainless steel (ASTM F138). All the specimens were obtained from Smith \& Nephew Orthopaedics Inc. (Memphis, TN, USA). The five kinds of test specimens were polished using a centrifugal barrel finishing process. This process involved the use of proprietary polishing compounds (trade secrets) for Oxinium, while a polishing cloth and diamond slurry (Maruto Instrument Co. Ltd., Tokyo, Japan; $1 \mu \mathrm{m}$ particle diameter) was used for the other four materials.

\section{Surface analysis}

Micrographs of the surface of the specimen disks were obtained using a field emission scanning electron microscope (SEM) (JSM 6610LV; JEOL Ltd, Tokyo, Japan). The micrographs were taken at two randomly chosen areas on each specimen (one in a central position and one at $1-1.5 \mathrm{~mm}$ in from the outer edge). The surface morphology and roughness of the specimens were measured by means of a three-dimensional (3D) measuring laser microscope (OLS4000, Shimadzu Corp, Tokyo, Japan) with a cutoff value $(\lambda \mathrm{c})$ of $80 \mu \mathrm{m}$ at room temperature. Three readings were made of each surface on three random samples, and the average roughness $(\mathrm{Ra})$ and mean roughness profile depth $(\mathrm{Rz})$ were used to characterize the roughness of the specimens. The initial contact angles of the surface of each specimen to deionized water (Milli- ${ }^{\circledR}$; EMD Millipore, Billerica, MA, USA) were measured by the drop method, using an automated contact angle measurement device (DSA30; Krüss GmbH, Hamburg, Germany) at room temperature. On each of four randomly selected specimens, three drops of deionized water $(2 \mu \mathrm{L})$ were analyzed (twelve measurements in total per product), and the left and the right contact angles of each drop were averaged.

\section{Experimental design}

The $S$. epidermidis strain RP62A (American Type Culture Collection [ATCC]35984; American Type Culture Collection, 
Manassas, VA, USA) was cultured in Trypticase ${ }^{\mathrm{TM}}$ Soy Broth (TSB) (BD Biosciences, Franklin Lakes, NJ, USA) at $37^{\circ} \mathrm{C}$ for 6 hours to create a bacterial suspension of $7.5 \times 10^{7}$ colony-forming units (CFU)/mL (logarithmic growth: optical density [OD] 600=0.2; pH 7.0). In this research, we only used a PIA-producing strain that was determined by reverse transcription polymerase chain reaction (RT-PCR) to be positive for the $i c a-A$ gene. ${ }^{30}$ Before the experimental procedure, all test specimens were sterilized by way of ultrasonic cleaning and steam autoclaving $\left(121^{\circ} \mathrm{C}\right)$. Then, $2 \mu \mathrm{L}$ of the bacterial suspension was dropped on the specimen, which was then placed at room temperature for 60 minutes. The specimens were then rinsed twice with phosphate-buffered saline (PBS) (Sigma-Aldrich Corp, St Louis, MO, USA), pH 7.0, to remove any unbound cells. The surface of three samples of each biomaterial were fixed with ethanol, stained with crystal violet, and imaged using a digital optical microscope (VHX-100; Keyence, Osaka, Japan). Other samples to be used to measure bacterial adhesion were transferred into sterile conical tubes (Falcon ${ }^{\circledR}$; BD Biosciences, Franklin Lakes, NJ, USA) containing $5 \mathrm{~mL}$ of fresh TSB medium. The tubes were vortexed at full speed for 1 minute and then placed in an ultrasonic bath and sonicated for 15 minutes at $120 \mathrm{~W}$, to release the attached cells from the biomaterial. After an additional vortex step, the specimen was taken out, and the bacterial separation from the surface of each specimen, on which no remaining attached bacteria were observed, was confirmed by digital optical microscope. The remaining suspensions were serially diluted with PBS and cultured at $37^{\circ} \mathrm{C}$ for 48 hours with a Compact Dry TC culture kit (Nissui Pharmaceutical Co, Ltd, Tokyo, Japan). The CFUs were counted to determine the number of viable adherent bacteria, and the bacterial density $(\mathrm{CFU} / \mathrm{mL})$ was calculated. The above procedure was performed twelve times for each material. As well as using uniform conditions for the bacteria, the five kinds of specimens were treated at the same time, and the experiments themselves were repeated using a uniform procedure to eliminate the effect of environmental factors.

\section{Statistical analysis}

The means and standard deviations of the topographic parameters of the specimens $(n=6)$, contact angles $(n=12)$, and viable adherent bacteria densities $(n=12)$ were analyzed for the different materials using SPSS 10.0 statistical software (SPSS Inc., Chicago, IL, USA). The statistical analysis was performed using one-way analysis of variance (ANOVA), multiple comparison tests, and the Tukey-Kramer and Bonferroni-Dunn multiple comparison tests for the post hoc analysis. The value of statistical significance was set at $P<0.05$.

\section{Results}

Field emission SEM images of the prepared surfaces of the disks are shown in Figure 1. Although there were some fine polishing microtraces and marks of diameter 10 to $200 \mu \mathrm{m}$ homogeneously distributed over the sample,
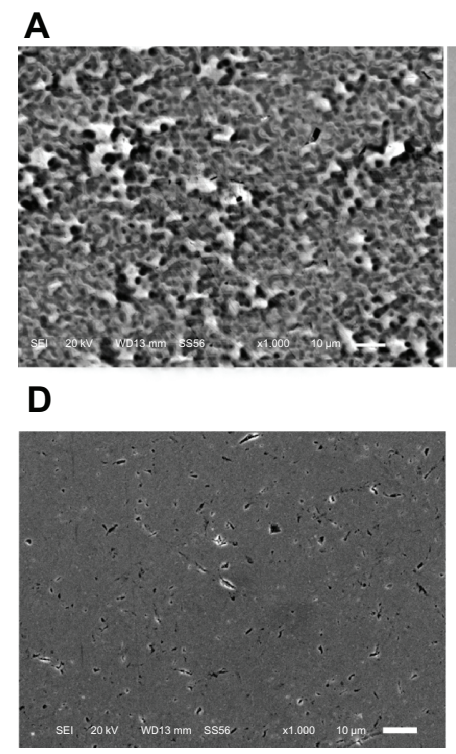

B

C

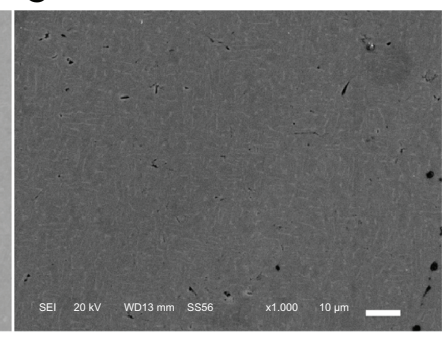

E

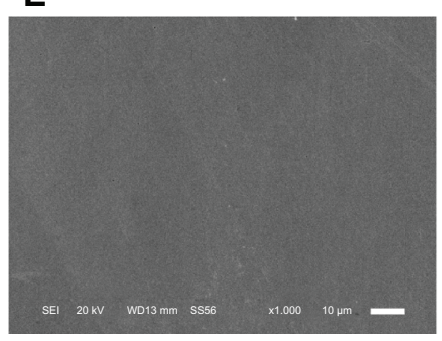

Figure I SEM micrographs.

Notes: The images show Oxinium (A), Co-Cr-Mo (B), Ti-6Al-4V (C), CP-Ti (D), and stainless steel (E). Although a few polishing microtraces and marks were observed, all specimens had a generally featureless and smooth surface. Original magnification $\times 1000$ (Scale bar $=10 \mu \mathrm{m})$.

Abbreviations: Co-Cr-Mo, cobalt-chromium-molybdenum alloy; CP-Ti, commercially pure titanium; SEM, scanning electron microscope; Ti-6Al-4V, titanium alloy. 
all the specimens were observed to be generally featureless, with a smooth surface topography. The numerous micropore- or coral-like structures of the Oxinium, seen at the standard detector SEM, indicated the difference in configuration between zirconium ceramic and zirconiumniobium alloy. The mean surface roughness parameters for each type of specimen are shown in Table 1. Co-Cr-Mo (mean $\mathrm{Ra}=2.3 \mathrm{~nm}$ ) and stainless steel (mean $\mathrm{Ra}=1.4 \mathrm{~nm}$ ) had significantly smoother surfaces than the Oxinium (mean Ra $=7.5 \mathrm{~nm}$ ), Ti-6Al-4V (mean $\mathrm{Ra}=4.8 \mathrm{~nm}$ ), and $\mathrm{CP}-\mathrm{Ti}($ mean $\mathrm{Ra}=5.4 \mathrm{~nm}$ ). However, all the specimens had comparatively smooth surfaces and recorded a low average roughness $(\mathrm{Ra}<10 \mathrm{~nm}$ ). One-way ANOVA indicated significant differences in the water contact angles between the various materials. Post hoc analysis revealed the highest water contact angle was for $\mathrm{Co}-\mathrm{Cr}-\mathrm{Mo}$, followed by stainless steel, CP-Ti, and Ti-6Al-4V. Oxinium yielded the lowest water contact angle (Table 2). Digital microscopic observations revealed bacteria of an aggregated and colonized appearance (small colonies) adhering to the surface of all the specimens (Figure 2). Figure 3 shows the results of the adhesion of $S$. epidermidis to the various specimens. The viable adhered cell count $\left(\times 10^{5} / \mathrm{mL}\right)$ was an average of $9.3 \pm 3.0$ for Oxinium, $9.1 \pm 5.0$ for Co-Cr-Mo, $13.5 \pm 3.1$ for Ti-6Al-4V, $16.7 \pm 8.1$ for CP-Ti, and $14.3 \pm 2.9$ for stainless steel. Therefore, the amounts of $S$. epidermidis that adhered to the Oxinium and Co-Cr-Mo specimens were significantly lower than the amounts that adhered to CP-Ti $(P<0.01)$.

\section{Discussion}

In this in vitro study, we compared the capabilities of PIApositive $S$. epidermidis, the preeminent cause of implantrelated infection, to adhere to five types of biomaterials, investigating substratum surface properties, such as surface

Table I Surface roughness

\begin{tabular}{lll}
\hline & \multicolumn{2}{l}{ Roughness $(\mathbf{n m})$} \\
\cline { 2 - 3 } & $\mathbf{R a}$ & $\mathbf{R z}$ \\
\hline Oxinium & $7.5 \pm 0.5^{\mathrm{b}, \mathrm{ce} e}$ & $49.5 \pm 3.8^{\mathrm{b}, \mathrm{e}}$ \\
Co-Cr-Mo & $2.3 \pm 0.5^{\mathrm{a}, \mathrm{c}, \mathrm{d}}$ & $17.2 \pm 7.5^{\mathrm{a}, \mathrm{c}, \mathrm{d}}$ \\
Ti-6AI-4V & $4.8 \pm 1.9^{\mathrm{a}, \mathrm{b}, \mathrm{e}}$ & $39.5 \pm 16.4^{\mathrm{b}, \mathrm{e}}$ \\
CP-Ti & $5.4 \pm 1.2^{\mathrm{b}, \mathrm{e}}$ & $35.8 \pm 7.8^{\mathrm{b}, \mathrm{e}}$ \\
Stainless steel & $1.4 \pm 0.5^{\mathrm{a}, \mathrm{c}, \mathrm{d}}$ & $10.0 \pm 1.3^{\mathrm{a}, \mathrm{c}, \mathrm{d}}$ \\
\hline
\end{tabular}

Notes: Data were expressed as a mean \pm SD. a $P<0.01$ compared with Oxinium; ${ }^{b} P<0.0$ l compared with Co-Cr-Mo; ${ }^{c} P<0.01$ compared with Ti-6Al-4V; ${ }^{d} p<0.01$ compared with $\mathrm{CP}-\mathrm{Ti}$; and $\mathrm{e}<<0.0 \mathrm{I}$ compared with stainless steel.

Abbreviations: Co-Cr-Mo, cobalt-chromium-molybdenum alloy; $\mathrm{CP}-\mathrm{Ti}$, commercially pure titanium; $\mathrm{Ra}$, arithmetic mean of the departures of the roughness profile from the profile center line; $R z$, average distance between the highest peak and the lowest valley; $\mathrm{SD}$, standard deviation; Ti-6Al-4V, titanium alloy. roughness and wettability. By defining which characteristics are important in adherence to biomaterials, it may be possible to formulate prosthetic devices that are less susceptible to bacterial adherence and less prone to infection.

The results of this study indicated that the total amount of viable bacteria that adhered to CP-Ti $(16.7 \pm 8.1 \times$ $10^{5} / \mathrm{mL}$ ) was significantly higher than in the case of Oxinium $\left(9.3 \pm 3.0 \times 10^{5} / \mathrm{mL}\right)$ and Co-Cr-Mo $\left(9.1 \pm 5.0 \times 10^{5} / \mathrm{mL}\right)$. It is possible that the more biocompatible CP-Ti provided a more favorable surface for bacterial adherence, ${ }^{29}$ whereas, it is also considered the Oxinium and Co-Cr-Mo surfaces prevented bacterial adhesion. Research has highlighted a particularly strong relationship between early bacterial adhesion and surface roughness; $;^{25-28}$ however, more recent studies have reported that in vivo, surface roughness below a threshold amount $(\mathrm{Ra}=200 \mathrm{~nm})$ does not affect bacterial adhesion. ${ }^{31,32}$ Although the extremely smooth surface of the Co-Cr-Mo (mean Ra =2.3 nm) used in this study could prevent bacterial adhesion compared with the CP-Ti (mean $\mathrm{Ra}=5.4 \mathrm{~nm}$ ), it is difficult to say whether the difference in the mean roughness between the two materials (about $3 \mathrm{~nm}$ Ra) significantly affected the quantity of bacterial adhesion. In fact, the stainless steel, which had the lowest surface roughness (mean $\mathrm{Ra}=1.4 \mathrm{~nm}$ ), showed a similar or higher degree of adhered $S$. epidermidis compared with Oxinium and Co-Cr-Mo $(P>0.05)$. It can be assumed that a surface roughness of less than $10 \mathrm{~nm}$ Ra has only a limited influence on S. epidermidis adherence.

Surface wettability (water contact angle) is another crucial element influencing bacterial adhesion. ${ }^{21,23,26}$ Boks et al reported that bond strengthening for four strains of S. epidermidis on a hydrophobic surface was fast and limited to a minor increase, while strengthening of the bonds on a hydrophilic surface increases significantly with contact time. ${ }^{33}$ As water molecules adjacent to a hydrophobic surface are not able to form hydrogen bonds with that surface (hydrophobic effect), bacterial adhesion to a hydrophobic specimen is brought about by an entropically favorable release of water molecules. The results of this research indicated that the amount of bacteria that adhered to the more hydrophobic Co-Cr-Mo surface was significantly less than that for the rather hydrophilic CP-Ti surface. Therefore, it is possible that the difference in bacterial adhesion is derived from the surface hydrophobicity. However, Tegoulia and Cooper found that a hydrophilic surface provides a stable interfacial water layer and prevents direct contact between bacteria and the surface. ${ }^{34}$ Oxinium, the most hydrophilic surface, exhibited fewer adhered bacteria than CP-Ti, in the present 
Table 2 Contact angles of deionized water (degree)

\begin{tabular}{lllll}
\hline Oxinium & Co-Cr-Mo & Ti-6Al-4V & CP-Ti & Stainless steel \\
\hline Contact angle (degree) & $104.1 \pm 5.7^{\mathrm{a}, \mathrm{a}, \mathrm{d}, \mathrm{e}}$ & & & \\
$73.9 \pm 5.6^{\mathrm{b}, \mathrm{d}, \mathrm{e}}$ & $77.0 \pm 5.3^{\mathrm{b}, \mathrm{d}, \mathrm{e}}$ & $89.2 \pm 7 .\left.\right|^{\mathrm{a}, \mathrm{b}, \mathrm{c}}$ & $90.0 \pm 2.3^{\mathrm{a}, \mathrm{b}, \mathrm{c}}$ \\
\hline
\end{tabular}

Notes: Data were expressed as a mean \pm SD. A greater water contact angle means a more hydrophobic surface. Oxinium had the smallest water contact angle, indicating the most hydrophilic surface. ${ }^{a} \mathrm{P}<0.0 \mathrm{I}$ compared with Oxinium; ${ }^{\mathrm{b}} \mathrm{P}<0.0 \mathrm{O}$ compared with $\mathrm{Co}-\mathrm{Cr}-\mathrm{Mo}$; ${ }^{\mathrm{c}} \mathrm{P}<0.0 \mathrm{l}$ compared with $\mathrm{Ti}-6 \mathrm{Al}-4 \mathrm{~V}$; ${ }^{\mathrm{d} P}<0.0 \mathrm{I}$ compared with $\mathrm{CP}-\mathrm{Ti}$; and e $P<0.0$ I compared with stainless steel.

Abbreviations: Co-Cr-Mo, cobalt-chromium-molybdenum alloy; CP-Ti, commercially pure titanium; SD, standard deviation; Ti-6Al-4V, titanium alloy.

A

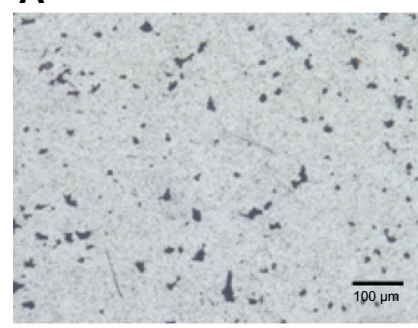

D

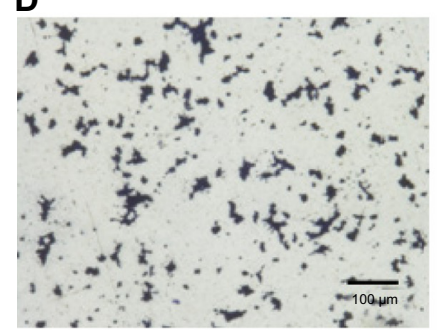

B

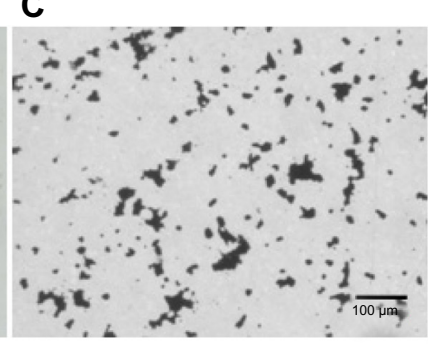

E

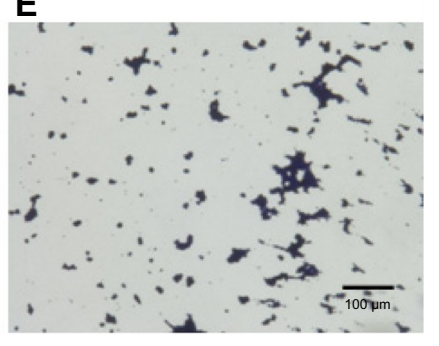

Figure 2 Digital optical micrographs.

Notes: Bacteria stained with $0.5 \%$ crystal violet were observed on the surface of: Oxinium (A), Co-Cr-Mo (B), Ti-6Al-4V (C), CP-Ti (D), and stainless steel (E). Original magnification $\times 450$ (Scale bar $=100 \mu \mathrm{m})$.

Abbreviations: Co-Cr-Mo, cobalt-chromium-molybdenum alloy; CP-Ti, commercially pure titanium; Ti-6Al-4V, titanium alloy.

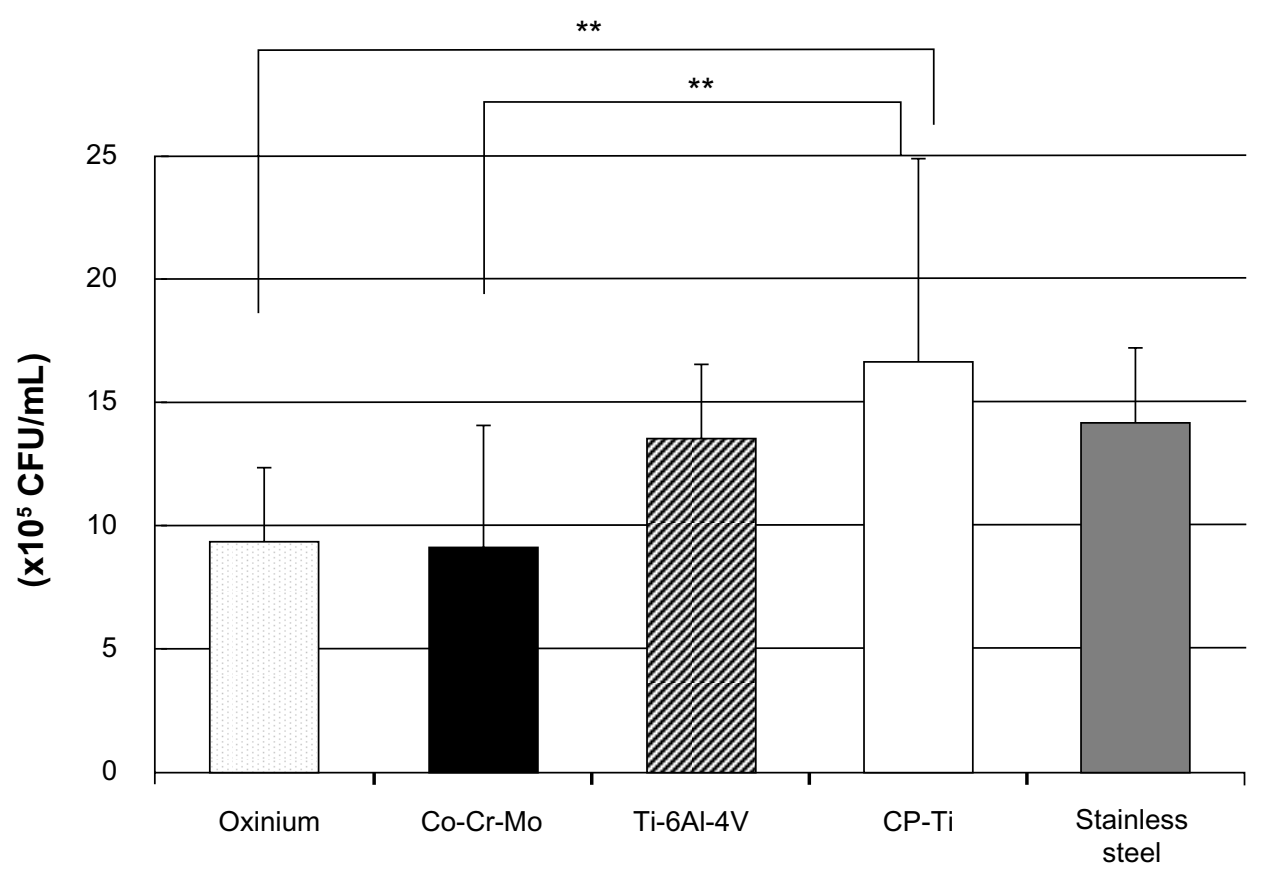

Figure 3 Viable adhered cell count of Staphylococcus epidermidis $\left(\times 10^{5} / \mathrm{mL}\right)$.

Notes: Mean and standard deviation are shown. ${ }^{*} * P<0.01$.

Abbreviations: Co-Cr-Mo, cobalt-chromium-molybdenum alloy; CP-Ti, commercially pure titanium; Ti-6Al-4V, titanium alloy. 
study. These observations indicate that bacterial adhesion is a multifactorial phenomenon, and surface roughness or wettability is not the only or main material surface characteristic influencing Staphylococcal adherence. However, it may suffice to say that the relatively smooth, hydrophobic surface of the Co-Cr-Mo in our study affected bacterial adhesion. Needless to say, additional physicochemical characteristics might have some influence on these results. Further study is needed to refine these results.

Several in vitro and in vivo studies found low bacterial adhesion on zirconia ceramics, which is compositionally similar but not equal to Oxinium. ${ }^{35,36}$ Poortinga et al indicated that the change in substratum potential, is due to charge transfer between the substratum and the bacteria during adhesion. ${ }^{37}$ With Oxinium having a ceramic surface, it is possible that the electron transfer or electrical potential may have been different from that of the other four metallic biomaterials and prevented bacterial attachment.

Several limitations must be noted in interpreting the data. The present study focused in particular on the first adherence process, before the generation of a biofilm, with quantification of the bacterial adhesion to various implants after a short period of 60 minutes. This time period corresponds to the localized adhesion of bacteria and is commonly used in microbiologic experiments that are solely focused on the bacterial adhesion process. ${ }^{38}$ Since contamination during an operation is thought to be the main cause of implant-related infection, early adhesion ability is considered to be clinically important.

Other clinical strains of bacteria associated with implant-related infection do not necessarily show similar adhesion properties. Moreover, the pathogenesis of prosthetic device infections is a complex process involving interactions between the pathogen, the biomaterial, and the host. An in vitro study cannot account for host defense and other in vivo factors, such as temperature, flow condition, and nutrition. However, it was possible to make a simple comparison of bacterial adhesion capability on five kinds of material surfaces actually used in clinical practice. The results of our in vitro research suggest a lower adhesion of S. epidermidis to Oxinium and Co-Cr-Mo than to CP-Ti at a negligible roughness level. In subsequent research, we need to assess the detailed mechanisms of bacterial adhesion under more sophisticated conditions, involving other strains of bacteria. However, this study allowed greater control of the experimental variables and produced fewer artifacts in the results.

\section{Conclusion}

We compared the adherence capability of $S$. epidermidis on the surfaces of five types of solid biomaterial. The amounts of bacteria that adhered to the biomaterial were significantly lower for Oxinium and Co-Cr-Mo than for CP-Ti.

\section{Acknowledgments}

The authors gratefully acknowledge Smith and Nephew Richards Ltd (Cirencester, UK) for kindly contributing the test components. This work was partially supported by the Japan Society for the Promotion of Science (JSPS) KAKENHI, grant number 24592236.

\section{Disclosure}

The authors report no conflicts of interest in this work.

\section{References}

1. Gristina AG. Biomaterial-centered infection: microbial adhesion versus tissue integration. Science. 1987;237(4822):1588-1595.

2. Stewart PS, Costerton JW. Antibiotic resistance of bacteria in biofilms. Lancet. 2001;358(9276):135-138.

3. Mangram AJ, Horan TC, Pearson ML, Silver LC, Jarvis WR. Guideline for prevention of surgical site infection, 1999. Centers for Disease Control and Prevention (CDC) Hospital Infection Control Practices Advisory Committee. Am J Infect Control. 1999;27(2):97-132.

4. Phillips CB, Barrett JA, Losina E, et al. Incidence rates of dislocation, pulmonary embolism, and deep infection during the first six months after elective total hip replacement. J Bone Joint Surg Am. 2003; 85-A(1):20-26.

5. Spangehl MJ, Masri BA, O’Connell JX, Duncan CP. Prospective analysis of preoperative and intraoperative investigations for the diagnosis of infection at the sites of two hundred and two revision total hip arthroplasties. J Bone Joint Surg Am. 1999;81(5):672-683.

6. Wymenga AB, van Horn JR, Theeuwes A, Muytjens HL, Slooff TJ. Perioperative factors associated with septic arthritis after arthroplasty. Prospective multicenter study of 362 knee and 2,651 hip operations. Acta Orthop Scand. 1992;63(6):665-671.

7. Chu VH, Crosslin DR, Friedman JY, et al. Staphylococcus aureus bacteremia in patients with prosthetic devices: costs and outcomes. $\mathrm{Am}$ J Med. 2005;118(12):1416.

8. Tsukayama DT, Estrada R, Gustilo RB. Infection after total hip arthroplasty. A study of the treatment of one hundred and six infections. J Bone Joint Surg Am. 1996;78(4):512-523.

9. Zimmerli W, Ochsner PE. Management of infection associated with prosthetic joints. Infection. 2003;31(2):99-108.

10. Mack D, Davies AP, Harris LG, Rohde H, Horstkotte MA, Knobloch JK. Microbial interactions in Staphylococcus epidermidis biofilms. Anal Bioanal Chem. 2007;387(2):399-408.

11. Fluckiger U, Ulrich M, Steinhuber A, et al. Biofilm formation, icaADBC transcription, and polysaccharide intercellular adhesin synthesis by staphylococci in a device-related infection model. Infect Immun. 2005; 73(3):1811-1819.

12. Hori K, Matsumoto S. Bacterial adhesion: From mechanism to control. Biochem Eng J. 2010;48(3):424-434.

13. AnYH, Friedman RJ. Concise review of mechanisms of bacterial adhesion to biomaterial surfaces. J Biomed Mater Res. 1998;43(3):338-348.

14. Heilmann C, Schweitzer O, Gerke C, Vanittanakom N, Mack D, Götz F. Molecular basis of intercellular adhesion in the biofilm-forming Staphylococcus epidermidis. Mol Microbiol. 1996;20(5):1083-1091. 
15. O'Gara JP. ica and beyond: biofilm mechanisms and regulation in Staphylococcus epidermidis and Staphylococcus aureus. FEMS Microbiol Lett. 2007;270(2):179-188.

16. Götz F. Staphylococcus and biofilms. Mol Microbiol. 2002;43(6): 1367-1378.

17. Olson ME, Garvin KL, Fey PD, Rupp ME. Adherence of Staphylococcus epidermidis to biomaterials is augmented by PIA. Clin Orthop Relat Res. 2006;451:21-24.

18. Hunter G, Dickinson J, Herb B, Graham R. Creation of oxidized zirconium orthopaedic implants. J ASTM Int. 2005;2(7).

19. Steinberg D, Sela MN, Klinger A, Kohavi D. Adhesion of periodontal bacteria to titanium, and titanium alloy powders. Clin Oral Implants Res. 1998;9(2):67-72.

20. Katsikogianni M, Missirlis YF. Concise review of mechanisms of bacterial adhesion to biomaterials and of techniques used in estimating bacteria-material interactions. Eur Cell Mater. 2004;8:37-57.

21. Busscher HJ, van der Mei HC. Physico-chemical interactions in initial microbial adhesion and relevance for biofilm formation. Adv Dent Res. 1997;11(1):24-32.

22. Gottenbos B, Van Der Mei HC, Busscher HJ, Grijpma DW, Feijen J. Initial adhesion and surface growth of Pseudomonas aeruginosa on negatively and positively charged poly(methacrylates). J Mater Sci Mater Med. 1999;10(12):853-855.

23. Balazs DJ, Triandafillu K, Chevolot Y, et al. Surface modification of PVC endotracheal tubes by oxygen glow discharge to reduce bacterial adhesion. Surf Interface Anal. 2003;35(3):301-309.

24. Henriques M, Azeredo J, Oliveira R. Adhesion of Candida albicans and Candida dubliniensis to acrylic and hydroxyapatite. Colloids Surf B Biointerfaces. 2004;33(3-4):235-241.

25. Scheuerman TR, Camper AK, Hamilton MA. Effects of substratum topography on bacterial adhesion. J Colloid Interface Sci. 1998;208(1): 23-33.

26. Teughels W, Van Assche N, Sliepen I, Quirynen M. Effect of material characteristics and/or surface topography on biofilm development. Clin Oral Implants Res. 2006;17 Supp1 2:S68-S81.

27. Subramani K, Jung RE, Molenberg A, Hammerle CH. Biofilm on dental implants: a review of the literature. Int J Oral Maxillofac Implants. 2009;24(4):616-626.
28. Quirynen M, van der Mei HC, Bollen CM, et al. An in vivo study of the influence of the surface roughness of implants on the microbiology of supra- and subgingival plaque. J Dent Res. 1993;72(9): 1304-1309.

29. Ha KY, Chung YG, Ryoo SJ. Adherence and biofilm formation of Staphylococcus epidermidis and Mycobacterium tuberculosis on various spinal implants. Spine. 2005;30(1):38-43.

30. Kajiyama S, Tsurumoto T, Osaki M, Yanagihara K, Shindo H. Quantitative analysis of Staphylococcus epidermidis biofilm on the surface of biomaterial. J Orthop Sci. 2009;14(6):769-775.

31. Quirynen M, Bollen CM. The influence of surface roughness and surface-free energy on supra- and subgingival plaque formation in man. A review of the literature. J Clin Periodontol. 1995;22(1):1-14.

32. Bollen CM, Lambrechts P, Quirynen M. Comparison of surface roughness of oral hard materials to the threshold surface roughness for bacterial plaque retention: a review of the literature. Dent Mater. 1997; 13(4):258-269.

33. Boks NP, Busscher HJ, van der Mei HC, Norde W. Bond-strengthening in staphylococcal adhesion to hydrophilic and hydrophobic surfaces using atomic force microscopy. Langmuir. 2008;24(22):12990-12994.

34. Tegoulia VA, Cooper SL. Staphylococcus aureus adhesion to selfassembled monolayers: effect of surface chemistry and fibrinogen presence. Colloids Surf B: Biointerfaces. 2002;24(3-4):217-228.

35. Al-Ahmad A, Wiedmann-Al-Ahmad M, Faust J, et al. Biofilm formation and composition on different implant materials in vivo. $J$ Biomed Mater Res Part B Appl Biomater. 2010;95(1):101-109.

36. Scarano A, Piattelli M, Caputi S, Favero GA, Piattelli A. Bacterial adhesion on commercially pure titanium and zirconium oxide disks: an in vivo human study. J Periodontol. 2004;75(2):292-296.

37. Poortinga AT, Bos R, Busscher HJ. Measurement of charge transfer during bacterial adhesion to an indium tin oxide surface in a parallel plate flow chamber. J Microbiol Methods. 1999;38(3):183-189.

38. Morand PC, Bille E, Morelle S, et al. Type IV pilus retraction in pathogenic Neisseria is regulated by the PilC proteins. EMBO J. 2004;23(9): 2009-2017.
International Journal of Nanomedicine

\section{Publish your work in this journal}

The International Journal of Nanomedicine is an international, peerreviewed journal focusing on the application of nanotechnology in diagnostics, therapeutics, and drug delivery systems throughout the biomedical field. This journal is indexed on PubMed Central,

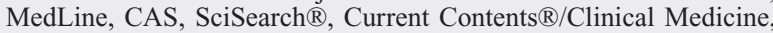

\section{Dovepress}

Journal Citation Reports/Science Edition, EMBase, Scopus and the Elsevier Bibliographic databases. The manuscript management system is completely online and includes a very quick and fair peer-review system, which is all easy to use. Visit http://www.dovepress.com/ testimonials.php to read real quotes from published authors. 